\title{
PENINGKATAN KETERAMPILAN PROSES SAINTIFIK DAN HASIL BELAJAR SISWA KELAS 4 SDN SLUNGKEP 02 TEMA PEDULI TERHADAP MAKHLUK HIDUP MENGGUNAKAN MODEL PROBLEM BASED LEARNING
}

\author{
Rismaerista Rini \\ hanyamae@yahoo.com \\ Sekolah Dasar Negeri Slungkep 02 Kayen - Pati \\ Mawardi \\ mawardiu@gmail.com \\ Pendidikan Guru Sekolah Dasar - FKIP - UKSW Salatiga
}

\begin{abstract}
ABSTRAK
Tujuan dari penelitian adalah untuk meningkatkan keterampilan proses saintifik dan hasil belajar siswa menggunakan model $P B L$ pada siswa kelas 4 SDN Slungkep 02. Jenis penelitian ini adalah Penelitian Tindakan Kelas (PTK). Teknik pengumpulan data menggunakan non tes dan tes. Instrumen penelitian berupa lembar observasi kegiatan mengajar guru dan aktivitas belajar siswa, keterampilan saintifik, dan hasil belajar. Teknik analisis yang digunakan adalah analisis deskriptif komparatif. Penerapan model $P B L$ dapat meningkatkan keterampilan proses saintifik dan hasil belajar siswa ditunjukkan pada aktivitas mengajar guru pada siklus I mencapai kategori baik (83), dan siklus II dengan kategori baik (90). Aktivitas belajar siswa pada siklus I mencapai Kategori cuku baik (79) dan siklus II dengan kategori baik sekali (91). Peningkatan keterampilan proses saintifik siklus I dengan kategori tinggi $(71,6 \%)$ dan siklus II berada pada kategori sangat tinggi (83\%). Hasil belajar muatan Bahasa Indonesia meningkat menjadi 78 pada siklus I dan 84 pada siklus II dengan ketuntasan belajar pada kategori tinggi (74\%) dan sangat tinggi (83\%). Hasil belajar muatan Matematika meningkat pada siklus I menjadi 77 dan ketuntasan belajar pada kategori tinggi (74\%). Pada siklus II hasil belajar menjadi 79 dengan ketuntasan belajar pada kategori tinggi (78\%). Hasil belajar IPA pada siklus I meningkat menjadi 77 dengan ketuntasan belajar pada kategori tinggi (70\%) dan siklus II sebesar 86 dengan ketuntasan belajar pada kategori sangat tinggi (87\%).
\end{abstract}

Kata kunci: keterampilan proses saintifik, hasil belajar, model $P B L$

\section{PENDAHULUAN}

Kurikulum 2013 menekankan penerapan pendekatan saintifik meliputi mengamati, menanya, mencoba, mengolah, menyajikan, menyimpulkan, dan mencipta untuk semua pelajaran (Sudarwan, 2013). Siswa diharapkan mampu 


\section{Peningkatan Keterampilan Proses Saintifik dan Hasil Belajar Siswa Kelas 4 SDN}

Slungkep 02...(Rismaerista Rini \& Mawardi)

mencari, mengkontruksi, dan menggunakan pengetahuan secara mandiri. Jadi pengetahuan tidak hanya bersumber dari guru, melainkan siswa dapat mencari pengetahuan dari berbagai sumber belajar di sekitarnya.

Proses pembelajaran kurikulum 2013 pada siswa SDN Slungkep 02 belum sepenuhnya menerapkan model pembelajaran yang tepat serta pendekatan saintifik yang diterapkan pada kurikulum 2013. Pada hasil pengamatan awal, hasil belajar siswa masih rendah dan sebagian besar belum mempunyai keterampilan saintifik. Proses pembelajaran siswa kelas 4 SDN Slungkep 02 pada tema Selalu Berhemat Energi hasilnya menunjukkan persentase keterampilan mengamati 57\%, menanya $54 \%$, mengumpulkan informasi $60 \%$, mengolah informasi $49 \%$, dan mengkomunikasikan 48\%. Besarnya persentase keterampilan saintifik ini menunjukkan keterampilan proses saintifik siswa pada kategori belum dapat mencapai kategori yang tinggi.

Rata-rata nilai ulangan harian pada tema Selalu Berhemat Energi pada muatan Bahasa Indonesia 60, Matematika 57, dan IPA 62. Persentase siswa yang mencapai kriteria ketuntasan belajar untuk Bahasa Indonesia 35\% dengan jumlah siswa yang mencapai kriteria ketuntasan belajar 8 siswa dan yang belum tuntas sebesar 65\% atau sebanyak 15 siswa, muatan Matematika sebanyak 7 siswa atau sebesar 30\% dan yang belum tuntas sebanyak 16 siswa atau sebesar 70\%, selanjutnya untuk muatan IPA sebanyak 9 siswa atau sebesar 39\% dan sebesar $61 \%$ belum tuntas atau sebanyak 14 siswa.

Menindaklanjuti hal tersebut, berbagai cara dilakukan untuk meningkatkan hasil keterampilan peserta di mana akan berdampak pada hasil belajar siswa. Namun guru belum menerapkan model pembelajaran yang tepat dalam mengembangkan keterampilan siswa. Guru masih menggunakan pembelajaran ceramah, tanya jawab, dan diskusi tanpa menggunakan model pembelajaran yang inovatif walaupun terlihat adanya keterampilan proses saintifik yang dilakukan.

Salah satu model pembelajaran yang dapat diterapkan adalah model Problem Based Learning. Menurut Suyatno (2009: 58) model pembelajaran berdasarkan masalah adalah proses pembelajaran yang titik awal pembelajaran dimulai berdasarkan masalah dalam kehidupan nyata siswa dirangsang untuk mempelajari masalah berdasarkan pengetahuan dan pengalaman telah mereka miliki sebelumnya (prior knowledge) untuk membentuk pengetahuan dan pengalaman baru. Dengan pembelajaran yang berkaitan langsung dengan kehidupan nyata siswa, maka siswa dapat memahami suatu masalah dalam kehidupan sehari-hari untuk menyelesaikan masalah yang ada.

Berdasarkan uraian yang telas dijelaskan, maka akan dilaksanakan penelitian tindakan kelas dengan judul "Peningkatan Keterampilan Proses 
Saintifik dan Hasil Belajar Siswa Kelas 4 SDN Slungkep 02 Tema Peduli terhadap Makhluk Hidup Menggunakan Model Problem Based Learning".

\section{KAJIAN PUSTAKA}

\section{Pembelajaran Tematik Terpadu}

Menurut Mulyasa (2014: 3) pembelajaran tematik diartikan sebagai pembelajaran yang menggunakan tema untuk mengaitkan beberapa mata pelajaran sehingga dapat memberikan pengalaman bermakna kepada siswa. Pembelajaran terpadu menggunakan tema sebagai pemersatu kegiatan pembelajaran yang memadukan beberapa mata pelajaran sekaligus dalam satu kali tatap muka, untuk memberikan pengalaman yang bermakna bagi siswa (Kemendikbud, 2014). Maka, pembelajaran tematik terpadu akhirnya dapat dirumuskan sebagai pembelajaran bermakna yang terdiri dari dari beberapa mata pelajaran yang diikat oleh suatu tema tertentu. Disadari atau tidak, siswa akan mempelajari semua atau sebagian muatan mata pelajaran dalam setiap pembelajaran.

Dalam satu kali tatap muka atau satu pembelajaran, siswa akan belajar materi berdasarkan tema yang dibagi dalam beberapa subtema dimana setiap subtema dilakukan dalam waktu satu minggu (enam hari), yaitu pembelajaran satu hingga pembelajaran enam. Jadi satu pembelajaran dialokasikan satu hari. Tema yang dipilih merupakan pengembangan dari standar kompetensi, kompetensi dasar, dan indikator.

\section{Model Problem Based Learning}

Pembelajaran berbasis masalah merupakan sebuah pendekatan pembelajaran yang menyajikan masalah kontekstual sehingga merangsang siswa untuk belajar (Daryanto, 2014: 29). Siswa harus mampu menyelesaikan masalah yang dihadapi di kehidupan nyata. Dengan bekerja bersama tim, siswa akan mampu belajar sesungguhnya dengan mengatasi hal-hal yang diberikan kepada mereka.

Menurut Barrow (dalam Miftahul Huda, 2013) mendefinisikan Problem Based Learning sebagai pembelajaran yang diperoleh melalui proses menuju pemahaman akan resolusi suatu masalah. Dalam Kemendikbud (2014) pembelajaran berbasis masalah adalah pendekatan pembelajaran yang dilakukan untuk memecahkan permasalahan yang diangkat oleh guru dan siswa. Maka siswa diharapkan mampu memahami masalah yang ada kemudian menyelesaikan secara mandiri ataupun berkelompok dalam menggali informasi dan memecahkan masalah.

Prosedur pelaksanaan model Problem Based Learning menurut Mulyasa (2014: 145) adalah (1) mengorientasi siswa terhadap masalah, (2) mengorganisasi 
siswa untuk belajar, (3) membimbing penyelidikan individual maupun kelompok, (4) mengembangkan dan menyajikan hasil karya, dan (6) menganalisis dan mengevaluasi proses pemecahan masalah.

\section{Keterampilan Saintifik}

Keterampilan saintifik adalah keterampilan khususnya pada siswa, untuk berpikir secara ilmiah dalam menghadapi dan memecahkan masalah. Dengan demikian, diharapkan siswa dapat lebih kritis terhadap suatu masalah yang ada.

Komponen keterampilan ilmiah meliputi kemampuan mengamati, menanya, mencoba, mengolah, menyajikan, menyimpulkan, mengevaluasi, dan mencipta. Komponen-komponen tersebut bukanlah suatu proses pembelajaran secara utuh, namun setiap pembelajaran setidaknya hanya mencakup beberapa komponen tersebut.

Pembatasan komponen dalam penelitian ini meliputi kegiatan mengamati, menanya, mengumpulkan informasi, mengolah informasi, dan mengkomunikasikan. Tujuan pembelajaran dengan pendekatan saintifik adalah (1) meningkatkan kemampuan intelek, khususnya kemampuan berpikir tingkat tinggi siswa, (2) membentuk kemampuan siswa dalam menyelesaikan suatu masalah secara sistematik, (3) terciptanya kondisi pembelajaran dimana siswa merasa bahwa belajar itu merupakan suatu kebutuhan, (4) diperolehnya hasil belajar yang tinggi, (5) melatih siswa dalam mengomunikasikan ide-ide, khususnya dalam menulis artikel ilmiah, dan (6) mengembangkan karakter siswa (Daryanto, 2014: 54).

Keterampilan saintifik terlihat pada cakupan materi pembelajaran pada subtema Hewan dan Tumbuhan di Lingkungan Rumahku, dan subtema Keberagaman Makhluk Hidup di Lingkunganku. Siswa dapat menyelesaikan masalah yang disajikan, misalnya sajian gambar hewan yang hanya separuh diminta untuk membuatnya agar menjadi gambar yang utuh. Dalam kegiatan tersebut, siswa juga mampu untuk memberikan contoh gambar hewan lain dengan teknik menggambar yang sama yang telah mereka lakukan sebelumnya.

Penilaian Autentik dalam Pembelajaran Tema Peduli terhadap Makhluk Hidup

Penilaian autentik adalah pengukuran yang bermakna secara signifikan atas hasil belajar siswa untuk ranah sikap, keterampilan, dan pengetahuan (Daryanto, 2014: 113). Jenis-jenis penilaian autentik antara lain penilaian kinerja, penilaian proyek, portofolio dan penilaian tertulis.

Dalam penelitian kali ini, peneliti menggunakan penilaian tertulis untuk mengetahui hasil belajar siswa menggunakan model Problem Based Learning berupa soal pilihan ganda dan penilaian kinerja berupa pengamatan keterampilan 
proses saintifik untuk mengetahui seberapa tinggi minat siswa mengikuti pembelajaran dengan keterampilan saintifik yang diharapkan.

Pada tema Peduli terhadap Makhluk Hidup, penilaian autentik mencakup semua materi pada masing-masing subtema yang dipelajari. Di antaranya dalam pengamatan, guru dapat mengamati siswa dalam menyelesaikan masalah dengan menggunakan rubrik saintifik yang disediakan yang terdiri dari 5 keterampilan yang diamati di antaranya adalah mengamati, menanya, mengumpulkan infornasi, mengolah informasi, dan mengkomunikasikan. Selanjutnya guru dapat menilai hasil belajar siswa di akhir pembelajaran siklus yang dilakukan.

\section{METODE PENELITIAN}

Tempat penelitian dilaksanakan di SD N Slungkep 02. Sekolah ini terletak di pinggir desa Slungkep, di mana sebagai perbatasan dengan desa lainnya sehingga letaknya cukup strategis. SD Negeri Slungkep 02 ini terbilang cukup lengkap dengan 6 ruang kelas, 1 ruang guru, 1 ruang perpustakaan, dan 1 ruang UKS serta tempat parkir yang cukup luas untuk guru dan siswa. Halaman luas SD Negeri Slungkep 02 dan suasananya yang rindang menjadikan sekolah ini terpilih sebagai sekolah sasaran adiwiyata. Selain sarana dan prasarana yang memadai, sekolah ini juga termasuk sekolah berprestasi di tingkat kecamatan Kayen yang dibuktikan dengan banyaknya prestasi lomba yang diraih.

Penelitian dilaksanakan pada awal tahun pelajaran 2014/2015 semester gasal. Penentuan waktu penelitian mengacu pada kalender akademik sekolah karena Penelitian Tindakan Kelas memerlukan beberapa siklus yang membutuhkan proses belajar mengajar yang efektif dan efisien. Penelitian ini dilaksanakan selama 4 bulan yaitu bulan September sampai dengan bulan Desember 2014. Pada bulan September dipergunakan peneliti untuk mengadakan persiapan, yaitu menyusun proposal penelitian dan instrumen yang diperlukan. Setelah itu pada bulan Oktober minggu ke-3, peneliti mulai melaksanakan penelitian tindakan kelas siklus I. Pada minggu ke-3 pembelajaran selanjutnya peneliti melanjutkan penelitian tindakan kelas pada siklus II. Bulan November sampai Desember peneliti melakukan pengolahan data hasil penelitian, membuat laporan hasil penelitian dan konsultasi laporan serta persiapan ujian. Subjek penelitian tindakan kelas ini yaitu siswa kelas 4 SDN Slungkep 02 pada semester gasal tahun pelajaran 2014/2015. Siswa kelas 4 SDN Slungkep 02 berjumlah 23 siswa, yang terdiri dari 12 laki-laki dan 11 perempuan dengan karakteristik yang heterogen. Tingkat kemampuan para siswa bervariasi, ada yang kurang, ada yang sedang dan ada pula beberapa siswa diatas rata-rata. Mereka berasal dari latar belakang orang tua yang berbeda pula. Sebagian orang tua mereka bermata pencaharian sebagai petani dan merantau ke luar kota. Sehingga sebagian dari 
mereka tidak mendapat perhatian belajar yang penuh dari orang tua.

Dalam penelitian ini variabel bebasnya adalah model Problem Based Learning, sedangkan variabel terikatnya adalah peningkatan kompetensi keterampilan saintifik dan kompetensi hasil belajar subtema Hewan dan Tumbuhan di Lingkungan Rumahku dan subtema Keberagaman Makhluk Hidup di Lingkunganku.

Penelitian tindakan kelas ini akan dilaksanakan dalam dua siklus, di mana setiap siklus dilaksanakan enam pembelajaran. Siklus I pada pembelajaran subtema Hewan dan Tumbuhan di Lingkungan Rumahku dan siklus II pada pembelajaran subtema Keberagaman Makhluk Hidup di Lingkunganku. Kemmis dan McTaggart menyatakan bahwa ada tiga tahap rencana tindakan yang utama dalam penelitian tindakan diantaranya adalah: perencanaan (planning), tindakan (acting) dan pengamatan (observing), serta refleksi (reflecting) (Arikunto, 2010:137).

Teknik yang digunakan untuk mengumpulkan data berbentuk tes, observasi dan dokumentasi. Tes digunakan untuk mengetahui peningkatan hasil belajar siswa selama kegiatan pembelajaran subtema Hewan dan Tumbungan di Lingkungan Rumahku, dan subtema Keberagaman Makhluk Hidup di Lingkunganku dengan masing-masing 15 butir soal tiap siklus. Sebelum instrumen diujikan terlebih dahulu dianalisis uji validitas dan reliabilitas menggunakan SPSS Inc PASW Statistics 18. Lembar observasi meliputi pengamatan keterampilan proses saintifik yang meliputi 5 keterampilan yang diamati oleh penulis dan yang diamati oleh observer adalah kegiatan mengajar guru dan aktivitas belajar siswa yang masing-masing terdiri dari 20 deskripsi yang diamati. Dokumentasi digunakan untuk mengumpulkan data-data yang berupa bahan tertulis ataupun film.

\section{HASIL DAN PEMBAHASAN}

\section{Deskripsi Hasil Tiap Siklus dan Antar Siklus}

Setelah melakukan analisa terhadap data yang diperoleh dari dua siklus yang dilaksanakan, maka dapat disimpulkan bahwa penerapan model $P B L$ pada tema Peduli terhadap Makhluk Hidup menunjukkan peningkatan keterampilan proses saintifik dan hasil belajar siswa yang ditunjukkan oleh persentase ketuntasan hasil belajar siswa.

Pada siklus I pengamatan terhadap aktivitas guru mencapai skor 83 . Dengan demikian, pengamatan aktivitas guru dalam penerapan model pembelajaran mencapai kategori indikator keberhasilan, yaitu baik. Sedangkan aktivitas belajar siswa belum memenuhi kategori yang diharapkan, yaitu baik. Jumlah skor menunjukkan angka 79 mencapai kategori cukup baik. Walaupun 
hanya selisih sedikit untuk memenuhi kategori baik, namun aktivitas belajar siswa pada penerapan model pembelajaran belum memenuhi indikator keberhasilan.

Pada siklus II pengamatan terhadap aktivitas guru mencapai skor 90. Dengan demikian, pengamatan aktivitas guru dalam penerapan model pembelajaran mencapai kategori indikator keberhasilan, yaitu baik. Sedangkan aktivitas belajar siswa menunjukkan peningkatan dari aktivitas belajar pada siklus sebelumnya. Aktivitas belajar siswa mencapai jumlah skor 91 dengan kategori baik sekali. Dengan demikian aktivitas belajar siswa pada siklus II mencapai indikator keberhasilan yang diharapkan peneliti.

Selanjutnya akan ditunjukkan perbandingan ketuntasan hasil belajar Bahasa Indonesia tiap siklus.

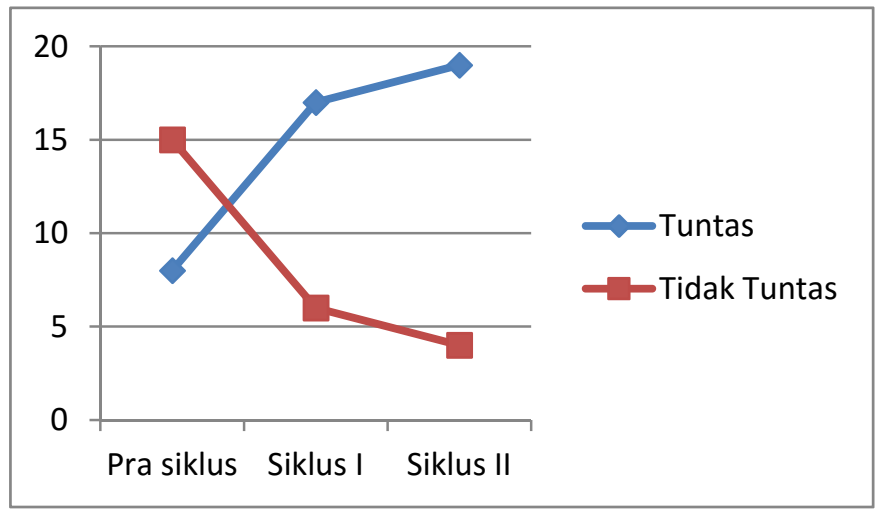

\section{Grafik 1. Perbandingan Ketuntasan Hasil Belajar Muatan Bahasa Indonesia Tiap Siklus}

Dari grafik 1 di atas, diperoleh ketuntasan belajar pada muatan Bahasa Indonesia pra siklus mencapai 8 siswa (35\%) dan yang tidak tuntas sebanyak 15 siswa $(65 \%)$. Pada siklus I terjadi peningkatan persentase yang mencapai ketuntasan belajar yaitu 17 siswa atau mencapai $74 \%$ dan mengalami peningkatan pada siklus II mencapai $83 \%$ atau sebanyak 19 siswa dan yang tidak tuntas sebanyak 4 siswa (17\%). Pada siklus I yang belum mencapai ketuntasan belajar sebanyak 7 siswa (30\%).

Berikut ini perbandingan ketuntasan hasil belajar muatan Matematika ditunjukkan pada grafik 2. Pada grafik 2 menunjukkan banyaknya siswa yang mencapai kriteria ketuntasan belajar hanya 8 pada pra siklus, 17 siswa pada siklus I, dan 18 siswa pada siklus II. Adapun yang tidak tuntas pada siklus I sebanyak 15 siswa, kemudian mengalami penurunan pada siklus I dan siklus II masing-masing 6 siswa dan 5 siswa. 
Peningkatan Keterampilan Proses Saintifik dan Hasil Belajar Siswa Kelas 4 SDN Slungkep 02...(Rismaerista Rini \& Mawardi)

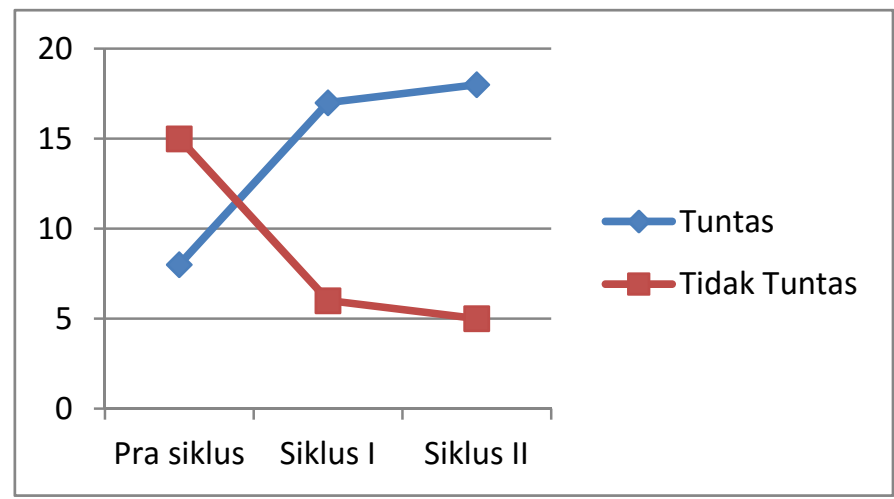

\section{Grafik 2. Perbandingan Ketuntasan Hasil Belajar Muatan Matematika Tiap Siklus}

Selanjutnya perbandingan ketuntasan hasil belajar muatan IPA disajikan pada grafik 3 berikut ini.

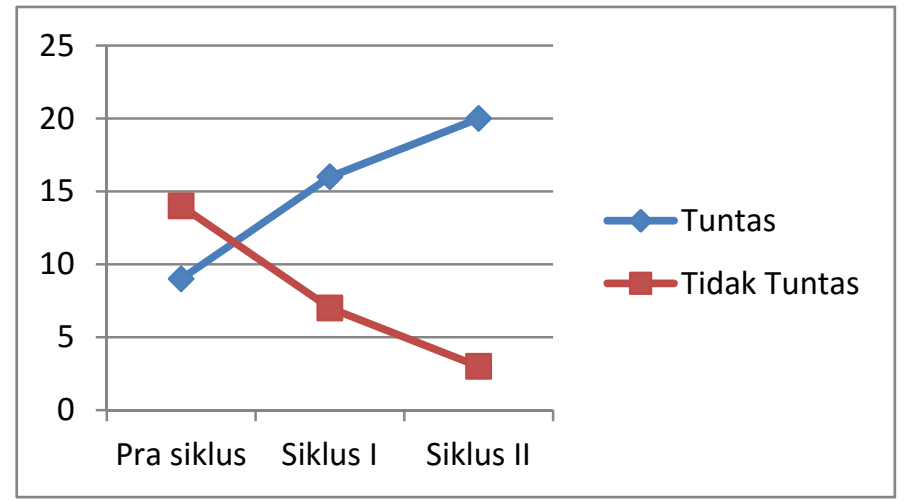

\section{Grafik 3. Perbandingan Ketuntasan Hasil Belajar Muatan IPA Tiap Siklus}

Pada grafik 3 menunjukkan ditunjukkan 9 siswa dapat memenuhi kriteria ketuntasan belajar pada pra siklus, lalu meningkat 16 siswa, dan 20 siswa pada siklus II. Siswa yang belum mampu mencapai kriteria ketuntasan belajar pada pra siklus mencapai 14 siswa, siklus I 7 siswa, dan 3 siswa pada siklus II.

Berikut ini (pada grafik 4) disajikan perbandingan keterampilan proses saintifik. Pada grafik nampak bahwa rata-rata setiap keterampilan proses mengalami peningkatan persentase setelah dilakukan tindakan. Keterampilan mengamati mengalami peningkatan dari $57 \%$ menjadi $74 \%$ pada siklus I dan siklus II meningkat menjadi $85 \%$. Keterampilan menanya menunjukkan persentase awal sebesar $54 \%$ meningkat $17 \%$ menjadi $71 \%$ pada siklus I dan siklus II meningkat $11 \%$ menjadi $82 \%$. Keterampilan dalam mengolah informasi 
meningkat dari $49 \%$ menjadi $69 \%$ pada siklus I dan menjadi $80 \%$ pada siklus II. Untuk keterampilan mengkomunikasikan yang mempunyai persentase awal sebesar $48 \%$, meningkat menjadi $75 \%$ pada siklus I dan $82 \%$ pada siklus II.

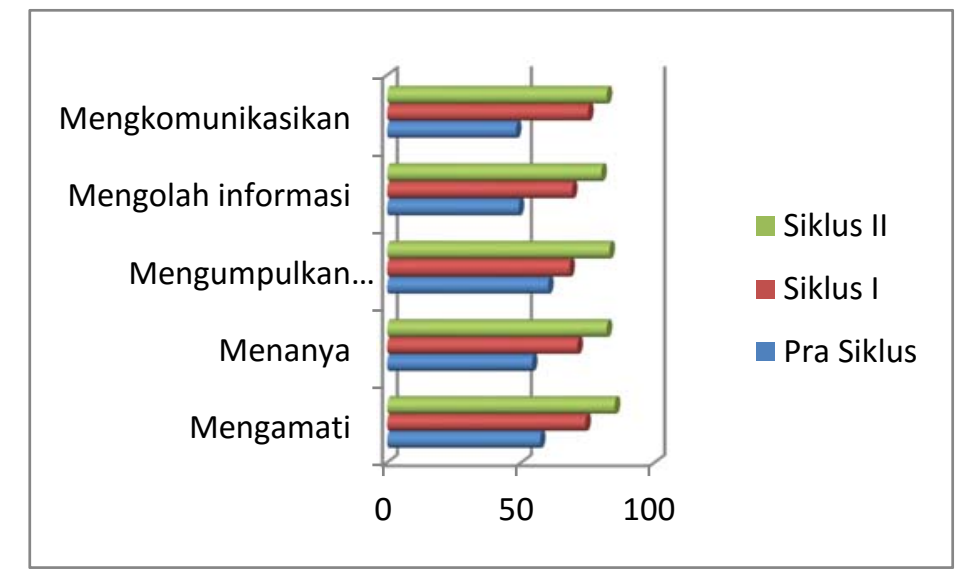

Grafik 4. Perbandingan Keterampilan Proses Saintifik Tiap Siklus

\section{PEMBAHASAN}

\section{Penerapan Model Problem Based Learning}

Pada siklus I aktivitas mengajar guru mencapai kategori baik (83) dan siklus II hanya mencapai kategori baik (90). Untuk aktivitas belajar siswa mencapai kategori cukup baik (79) dan siklus II mencapai kategori sangat baik (91). Ini menunjukkan penerapan model Problem Based Learning pada siklus II telah memenuhi indikator keberhasilan yang diharapkan dengan kriteria baik pada aktivitas mengajar guru dan baik sekali pada aktivitas belajar siswa.

Dari hasil yang telah diuraikan, maka penerapan model pembelajaran Problem Based Learning pada siswa kelas IV SDN Slungkep 02 selaras dengan penelitian yang dilakukan oleh Putri Asih Diyah Arini (2014) dan Ratna Dwi Pratiwi (2013).

\section{Peningkatan Keterampilan Proses Saintifik dan Hasil Belajar}

Pembelajaran menggunakan model Problem Based Learning dapat meningkatkan keterampilan proses saintifik pada kategori tinggi $(71,6 \%)$ pada rata-rata siklus I. Pada siklus II berada pada kategori sangat tinggi (83\%). Ratarata hasil belajar siswa pada muatan Bahasa Indonesia meningkat menjadi 78 pada siklus I dan 84 pada siklus II dengan masing-masing ketuntasan belajar mencapai $74 \%$ pada kategori tinggi dan $83 \%$ pada kategori sangat tinggi. Rata-rata hasil 


\section{Peningkatan Keterampilan Proses Saintifik dan Hasil Belajar Siswa Kelas 4 SDN}

Slungkep 02...(Rismaerista Rini \& Mawardi)

belajar muatan Matematika meningkat pada siklus I menjadi 77 dan ketuntasan belajar $74 \%$ pada kategori tinggi. Selanjutnya pada siklus II rata-rata hasil belajar menjadi 79 dengan ketuntasan belajar sebesar $78 \%$ pada kategori tinggi. Untuk rata-rata hasil belajar IPA pada siklus I meningkat menjadi 77 dan ketuntasan belajarnya $70 \%$ pada kategori tinggi, serta me-ningkat lagi pada siklus II sebesar 86 dengan ketuntasan belajar $87 \%$ pada kategori sangat tinggi. Hal ini menunjukkan bahwa rata-rata hasil belajar muatan Bahasa Indonesia, Matematika, dan IPA dengan penerapan model Problem Based Learning dapat meningkat dan ketuntasan belajar mencapai lebih dari 70\% dengan rata-rata hasil belajar mencapai kriteria sangat tinggi. Siswa yang tidak tuntas pada siklus II dikarenakan konsentrasi belajar siswa masih rendah dan kurangnya semangat dalam mengikuti pembelajaran yang berlangsung.

Hasil penelitian yang telah diuraikan di atas, penerapan model Problem Based Learning pada siswa kelas IV SDN Slungkep 02 mengalami peningkatan pada akhir siklus yang selaras dengan penelitian yang dilakukan oleh Eni Wulandari, H. Setyo Budi, dan Kartika Chrysti Suryandari (2013), Jamilah Candra Pratiwi, Siti Istiyati, dan Hartono (2014), dan Ratna Dwi Pratiwi (2013).

\section{PENUTUP}

\section{Simpulan}

Berdasarkan hasil penelitian dan pembahasan, dapat disimpulkan sebagai berikut:

1. Meningkatkan keterampilan proses saintifik dan hasil belajar siswa kelas 4 SDN Slungkep 02 yang ditunjukkan aktivitas mengajar guru pada kategori baik dan siklus II pada kategori baik. Aktivitas belajar siswa pada siklus I mencapai kategori cukup baik dan siklus II mencapai kategori baik sekali

2. Meningkatkan keterampilan proses saintifik pada siklus I mencapai kategori tinggi $(71,6 \%)$ dan siklus II pada kategori sangat tinggi (83\%). Hasil belajar muatan Bahasa Indonesia 78 pada siklus I dan 84 pada siklus II dengan masing-masing ketuntasan belajar $74 \%$ pada kategori tinggi dan $83 \%$ pada kategori sangat tinggi. Hasil belajar muatan Matematika 77 dengan ketuntasan belajar $74 \%$ pada kategori tinggi dan siklus II hasil belajar 79 dengan ketuntasan belajar sebesar $78 \%$ pada kategori tinggi. Pada siklus I hasil belajar IPA 77 dengan ketuntasan belajarnya $70 \%$ pada kategori tinggi dan siklus II sebesar 86 dengan ketuntasan belajar $87 \%$ pada kategori sangat tinggi. 


\section{Saran}

Saran yang diajukan dalam penelitian ini adalah sebagai berikut.

1. Siswa diharapkan siswa dapat meningkatkan lagi kemampuan proses saintifik khususnya pada keterampilan mengkomunikasikan agar lebih percaya diri.

2. Guru diharapkan untuk menerapkan model Problem Based Learning dan meningkatkan kemampuan dalam menciptkan pembelajaran yang aktif dan kreatif.

3. Sekolah disarankan untuk mendorong semangat guru dalam menerapkan model Problem Based Learning pada setiap kelas dengan muatan pelajaran lainnya.

\section{DAFTAR PUSTAKA}

Arikunto, Suharsimi. (2010). Prosedur Penelitian. Jakarta: PT. Rineka Cipta.

Arini, Putri Asih Diyah. (2014). Penerapan Model Problem Based Learning untuk Peningkatan Hasil Belajar Matematika Siswa Kelas V SD 7 Klumpit Kecamatan Gebog Kabupaten Kudus. Skripsi. Tidak diterbitkan. Universitas Muria Kudus.

Daryanto. (2014). Pembelajaran Tematik, Terpadu, Terintegrasi (Kurikulum 2013). Yogyakarta: Gava Media.

Huda, Miftahul. (2013). Model-model Pengajaran dan Pembelajaran. Yogyakarta: Pustaka Pelajar.

Kemendikbud. (2014). Materi Pelatihan Guru Implementasi Kurikulum 2013 Tahun 2014. Jakarta: BPSDMPK - PMP - Kemendikbud

Mulyasa. (2014). Guru dalam Implementasi Kurikulum 2013. Bandung: Remaja Rosdakarya.

Pratiwi, Jamilah Candra. (2014). Penelitian Scientific dengan Model Problem Based Learning (PBL) untuk Meningkatkan Keterampilan Berbicara. Jurnal Dikdatika Dwija Indria (SOLO). 2(11). 6-10.

Pratiwi, Ratna Dwi. (2013). Peningkatan Minat dan Hasil Belajar pada Materi Pecahan melalui Model Problem Based Learning di kelas V Sekolah Dasar Negeri Randugunting 4 Kota Tegal. Skripsi. Universitas Negeri Semarang.

Sudarwan. (2013). Pendekatan-pendekatan Ilmiah dalam Pembelajaran. Jakarta: Pusbangprodik.

Suyatno. (2009). Menjelajah Pembelajaran Inovatif. Surabaya: Masmedia Buana Pustaka.

Wulandari, Eni. (2013). Penerapan Model Problem Based Learning pada Pembelajaran IPA Siswa Kelas V SD. Dikdatika PGSD Kebumen. 2(1). 6065. 